\title{
Monosaccharide as a Central Scaffold Toward the Construction of Salicylate-Based Bidentate PTP1B Inhibitors via Click Chemistry
}

\author{
Yan-Hui Tang, ${ }^{*}$ Min Hu, Xiao-Peng He, Sando Fahnbulleh, Cui Li, Li-Xin Gao, ${ }^{\dagger}$ \\ Li Sheng, ${ }^{\dagger}$ Yun Tang, Jia Li, ${ }^{\dagger, *}$ and Guo-Rong Chen* \\ Key Laboratory for Advanced Materials and Institute of Fine Chemicals, and School of Pharmacy, \\ East China University of Science and Technology, Shanghai 200237, P. R. China \\ *E-mail: tangyanhui@ecust.edu.cn (Y.-H.Tang.); mrs_guorongchen@ecust.edu.cn (G.-R. Chen) \\ ${ }^{\dagger}$ National Center for Drug Screening, State Key Laboratory of Drug Research, Shanghai Institute of Materia Medica, Shanghai \\ Institutes of Biological Sciences, Chinese Academy of Sciences, Shanghai 201203, P. R. China. *E-mail: jli@mail.shcnc.ac.cn \\ Received November 1, 2010, Accepted January 21, 2011
}

\begin{abstract}
The discovery of carbohydrate-based bioactive compounds has recently received considerable interest in the drug development. This paper stresses on the application of 1-methoxy-O-glucoside as the central scaffold, whereas salicylic pharmacophores were introduced with diverse spatial orientations probing into the structural preference of an enzymatic target, i.e. protein tyrosine phosphatase 1B (PTP1B). By employing regioselective protection and deprotection strategy, 2,6-, 3,4-, 4,6- and 2,3-di-O-propynyl 1-methoxy- $O$-glucosides were previously synthesized and then coupled with azido salicylate via click chemistry in forming the desired bidentate salicylic glucosides with high yields. The inhibitory assay of the obtained triazolyl derivatives leads to the identification of the 2,3-disubstituted salicylic 1-methoxy- $O$-glucoside as the structurally privileged PTP1B inhibitor among this bidentate compound series with micromole-ranged $\mathrm{IC}_{50}$ value and reasonable selectivity over other homologous PTPs tested. In addition, docking simulation was conducted to propose a plausible binding mode of this authorized inhibitor with PTP1B. This research might furnish new insight toward the construction of structurally different bioactive compounds based on the monosaccharide scaffold.
\end{abstract}

Key Words : Monosaccharide, Structural preference, Click chemistry, Protein tyrosine phosphatase 1B (PTP1B) inhibitor

\section{Introduction}

Carbohydrates universally exist in nature governing a multitude of crucial biological and pathological events on cellular level. The synthesis of carbohydrate-based bioactive compounds has currently absorbed considerably many efforts as regards its natural abundance, structural diversity as well as high biocompatibility. ${ }^{1}$ For example, the two drugs namely, zanamivir and oseltamivir, approved to date in combating both influenza A and B were derived from a pyranoglycosyl scaffold via computational study. ${ }^{2}$

Indeed, the carbohydrate structure that contains multiple stereo-centers and reactive hydroxyl groups may favorably allow modification toward the construction of numerous structurally diverse glycomimetics. For instance, a 1-methoxy- $O$-glucoside has a primary hydroxyl group on C6 and three secondary hydroxyl groups respectively on $\mathrm{C} 2, \mathrm{C} 3$ and C4 with different reactivities and spatial orientations on its side chain, shown in Figure 1. Such a molecule would be desirable as a central scaffold with the introduced pharmacophores onto its readily modifiable side-chain positions with diverse spatial orientations for investigating the structural preference of drug targets. Moreover, the high biocompatibility of carbohydrate itself might also be considered as an essential merit for enhancing the bioavailability of the fabricated sugar-contained bioactive compounds.
Recent studies indicate that enhanced insulin sensitivity and ameliorated glycemic control, and resistance to dietinduced obesity were observed on protein tyrosine phosphatase 1B (PTP1B)-null mice, suggesting that the inhibition of PTP1B may represent a promising strategy to combat both type 2 diabetes and obesity. ${ }^{3,4}$ As a consequence, a large number of PTP1B inhibitors have been disclosed in the past decade, which mainly fell into competitive nonhydrolyzable phosphotyrosine (pTyr) surrogates. ${ }^{5}$ Meanwhile, noncompetitive inhibitors identified such as the aryl diketoacid derivatives that target the open conformation of WPD loop also enabled an alternative way for PTP1B inhibition. ${ }^{6}$

As shown in Figure 1, we have recently synthesized series of triazolyl salicylate-hydroxyl $O$-glycoside conjugates via $\mathrm{Cu}(\mathrm{I})$-catalyzed azide-alkyne 1,3-cycloaddition (click reaction). ${ }^{7}$ The sequential inhibitory assay identified these compounds as weak PTP1B inhibitors, $\left(\mathrm{IC}_{50}>50 \mu \mathrm{M}\right)$ possibly due to the lack of hydrophobic moieties for generating nonpolar interactions with the proper enzymatic surface. ${ }^{6,7}$ As a result, we seek to continuously progress our study toward the preparation of new PTP1B inhibitors based on triazole-linked salicylic $O$-glycosides which simultaneously comprise aryl groups via the versatile click chemistry. ${ }^{8-10}$

The strategy for preparing 'bidentate' inhibitors simultaneously access the catalytic site and a neighboring pocket such as the second phosphotyrosine site ${ }^{11}$ or the YRD motif has 


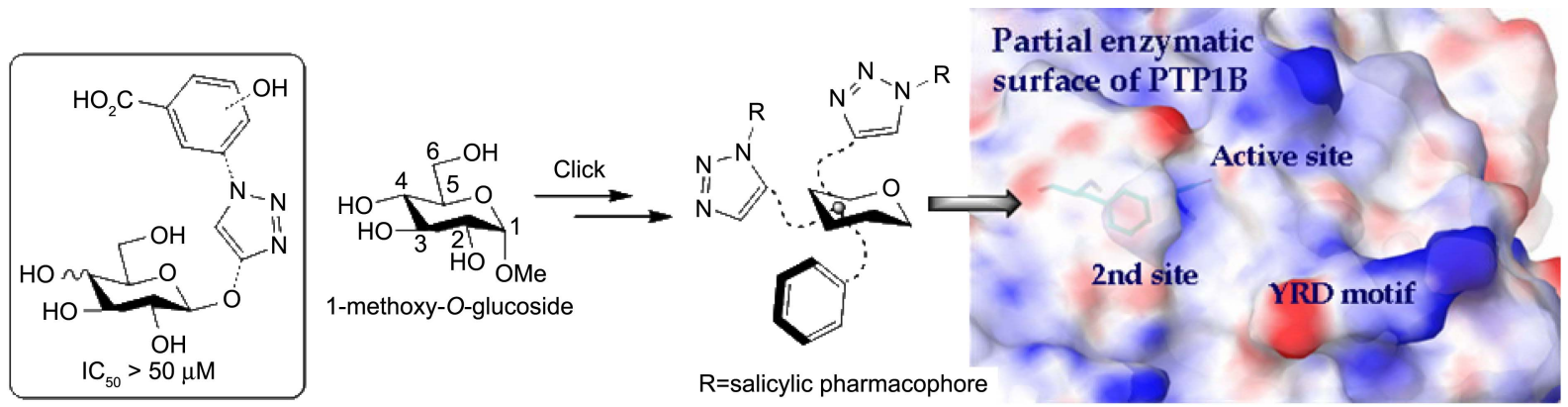

Figure 1. Depict the construction of bidentate PTP1B inhibitors via click reaction based on a glucosyl scaffold.

proven efficacious to achieve potent and selective PTP1B inhibition. ${ }^{5}$ We were consequently prompted to prepare bidentate inhibitors by introducing two salicylic pharmacophores $^{12,13}$ onto a 1-methoxy-O-glucosyl scaffold. The benzyl 2,6-, 3,4-, 4,6- and 2,3-disubstituted di-2-O-propynyl glucosides concomitantly containing two benzyl groups and two activated alkynyl functionalities were prepared to couple with the azido salicylate, forming the desired bidentate salicylic glucosides. The inhibitory activity of the synthesized products on PTP1B and other homologous PTPs was assessed and discussed. Furthermore, the plausible binding mode of the most bioactive product with PTP1B was proposed via docking simulation.

\section{Result and Discussion}

Synthesis. For the synthesis of the desired products, methyl 5-(3-azidopropoxy)-2-hydroxybenzoate 2 and di- $O$ propynyl 1-methoxy- $O$-glucosides 5-8 were first prepared. As shown in Scheme 1, the salicylic azide $\mathbf{2}$ was readily synthesized by the etherification of commercially available methyl 2,5-dihydroxybenzoate 3 with 1,3-dibromopropane in the presence of $\mathrm{K}_{2} \mathrm{CO}_{3}$ followed by azide substitution. A 3C-alkyl linkage was employed to build this salicylic azide for allowing adequate structural flexibilities toward the extension of the pharmacophores to appropriate docking sites.

The 2,6-di- $O$-propynyl glucoside $\mathbf{5}$ was synthesized by introducing propargyl bromide onto the 2,6-positions of the known 3,4-di- $O$-benzyl glucoside $\mathbf{5}^{\prime 13}$ in the presence of $\mathrm{NaH}$. Similarly, the synthesis of 4,6-di-O-propynyl glucoside 7 was realized by the $O$-propargylation of methyl 2,3di- $O$-benzyl- $\alpha$-D-glucopyranoside $7{ }^{\prime}{ }^{14}$ The benzylated 3,4di- $O$-propynyl glucoside 6 was then prepared from the selectively silylated $\mathbf{6}^{\prime 15}$ via a 3 -steps sequence which includes $O$-propargylation, $\mathrm{AcCl}$ catalyzed desilylation and $O$-benzylation. The preparation of 2,3-di- $O$-propynyl glucoside 8 was eventually achieved by $O$-propargylation of the known benzylidene derivative $\mathbf{8}^{\mathbf{1 6}}$ which was then converted to the benzyl derivative $\mathbf{8}$ by the removal of benzylidene group with TFA and the following $O$-benzylation as shown in Scheme 1.

The click reaction between the azide 2 and sugar alkynes 5-8 was then performed. As shown in Scheme 2, in the presence of 4 equiv. $\mathrm{Na}$ ascorbate and 2 equiv. $\mathrm{CuSO}_{4} \cdot 5 \mathrm{H}_{2} \mathrm{O}$, the Huisgen $[3+2]$ cycloaddition proceeded smoothly in a solvent mixture of water/ $\mathrm{CH}_{2} \mathrm{Cl}_{2}(1: 1, \mathrm{~V} / \mathrm{V})$ within $12 \mathrm{~h}$, affording the desired bis-triazolyl glucoside 9, 10, 11 and 12

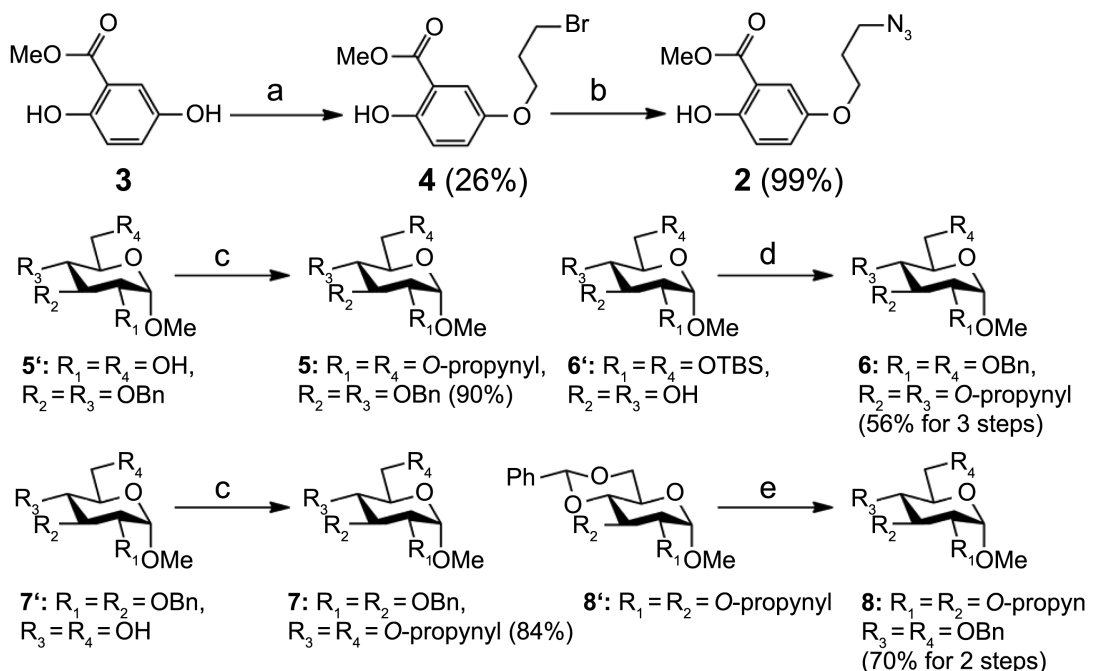

Scheme 1. Synthesis of the azide and sugar alkynes: Reagents and conditions: (a) 1,3-dibromopropane, $\mathrm{K}_{2} \mathrm{CO}_{3}, \mathrm{CH}_{3} \mathrm{CN}$, reflux. (b) $\mathrm{NaN}_{3}$, $\mathrm{CH}_{3} \mathrm{CN}$, reflux. (c) propargyl bromide, $\mathrm{NaH}, \mathrm{DMF}, 0{ }^{\circ} \mathrm{C}$-r.t. (d) (i) propargyl bromide, $\mathrm{NaH}$, DMF, $0{ }^{\circ} \mathrm{C}$-r.t.; (ii) $\mathrm{AcCl}$, $\mathrm{MeOH}$, r.t.; (iii) $\mathrm{BnBr}, \mathrm{NaH}$, DMF, $0{ }^{\circ} \mathrm{C}$-r.t. (e) (i) $\mathrm{TFA}$, $\mathrm{MeOH}$, r.t.; (ii) $\mathrm{BnBr}$, $\mathrm{NaH}$, DMF, $0{ }^{\circ} \mathrm{C}$-r.t. 

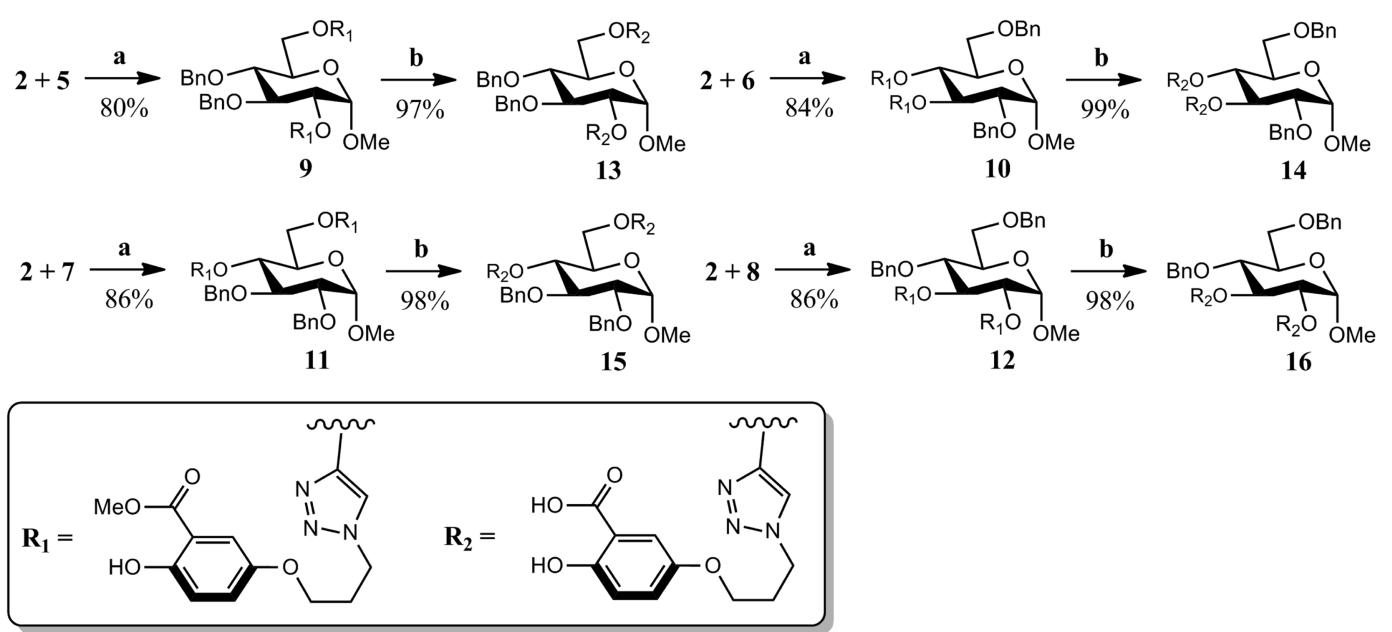

Scheme 2. Synthesis of the desired triazole-linked glucosyl salicylates: Reagents and conditions: (a) $\mathrm{CuSO}_{4} \cdot 5 \mathrm{H}_{2} \mathrm{O}, \mathrm{Na}$ ascorbate, $\mathrm{CH}_{2} \mathrm{Cl}_{2}$, water, r.t. (b) $\mathrm{LiOH} \cdot \mathrm{H}_{2} \mathrm{O}$, water, $\mathrm{THF}$, r.t.

in good yields of $80,84,86$ and $86 \%$, respectively. The following saponification with $\mathrm{LiOH} \cdot \mathrm{H}_{2} \mathrm{O}$ gave the free acids 13-16 in almost quantitative yields (97-99\%).

Inhibitory Assay. The inhibitory activity of the prepared triazole-linked glucosyl salicylic derivatives 13, 14, 15 and 16 on a panel of PTPs including PTP1B, TCPTP, LAR, SHP1 and SHP-2 was tested at the concentration of $100 \mu \mathrm{g} / \mathrm{mL}$ via our previously established methods. ${ }^{17}$ As listed in Table 1, the 3,4-disubstituted glucoside $\mathbf{1 4}$ was first found to be inactive on all PTPs tested. The 2,6- and 4,6-disubstituted glucosides 13 and 15 then exhibited similar inhibitory activities on PTP1B with $\mathrm{IC}_{50}$ values equal to 30 and $25 \mu \mathrm{M}$, respectively. Additionally, the 2,6-disubstituted compound 13 simultaneously displayed moderate inhibitory activity on SHP-1 $\left(\mathrm{IC}_{50}=59 \mu \mathrm{M}\right)$ and SHP-2 $\left(\mathrm{IC}_{50}=39 \mu \mathrm{M}\right)$ whereas both compounds 13 and $\mathbf{1 5}$ were not inhibitors of TCPTP, LAR and SHP-1 $\left(\mathrm{IC}_{50}>100 \mu \mathrm{M}\right)$. Eventually, to our delight, the 2,3-disubstituted glucoside 16 displayed further enhanced inhibitory activity on PTP1B compared to other bidentate salicylic glucosides assessed with an $\mathrm{IC}_{50}$ value $=7.7$ $\mu \mathrm{M}$. This inhibitor also exhibited good selectivity over TCPTP (7-fold) and excellent selectivity over LAR ( $>13$ fold), SHP-1 (> 13-fold) and SHP-2 (>13-fold).

Obviously, the four structurally diverse bidentate salicylic glucosides synthesized exhibited different PTP1B inhibitory potency as depicted above. The 3,4-disubstition on glucosyl

Table 1. Inhibitory activity of compounds $13,14,15$ and 16 on PTPs

\begin{tabular}{cccccc}
\hline \multirow{2}{*}{ Compd. } & \multicolumn{5}{c}{$\mathrm{IC}_{50}-\mu \mathrm{M}^{a}$} \\
\cline { 2 - 6 } & PTP1B & TCPTP & LAR & SHP-1 & SHP-2 \\
\hline $\mathbf{1 3}$ & 30.0 & $>100$ & $>100$ & 58.8 & 38.8 \\
$\mathbf{1 4}$ & $>100$ & $>100$ & $>100$ & $>100$ & $>100$ \\
$\mathbf{1 5}$ & 25.0 & $>100$ & $>100$ & $>100$ & $>100$ \\
$\mathbf{1 6}$ & 7.7 & 54.3 & $>100$ & $>100$ & $>100$ \\
\hline
\end{tabular}

${ }^{a}$ Values are means of three experiments. scaffold was proved unsuitable for achieving PTP1B inhibition whereas, both 2,6- and 4,6-disubsitituted glucosides exhibited moderate inhibitory activity toward PTP1B. Notably, the 2,3-disubstitution pattern finally leads to an at least 3fold increased inhibitory activity of compound $\mathbf{1 6}$ compared to that of the rest (Table 1). These results unambiguously supported the notion of proposing the monosaccharide as a central scaffold for probing the structural preference of PTP1B.

Furthermore, the inhibitory activity of compound $\mathbf{1 6}$ (IC $_{50}$ $=7.7 \mu \mathrm{M})$ is almost 7-fold improved compared to that of our previously synthesized salicylic glycosides $\left(\mathrm{IC}_{50}>50 \mu \mathrm{M}\right.$, Fig. 1) with exposed hydroxyl groups, demonstrating the existence of the benzyl groups on the glucosyl scaffold necessary for enhancing PTP1B binding affinity.

Docking Simulation. We then tended to propose a plausible binding mode of the inhibitor 16 with PTP1B by starting with a crystal structure in complex with a reference ligand (PDB code: 3EB1, resolution: $2.40 \AA$ ). Water was removed from the original structure, and the remaining protein was prepared using the Protein preparation wizard

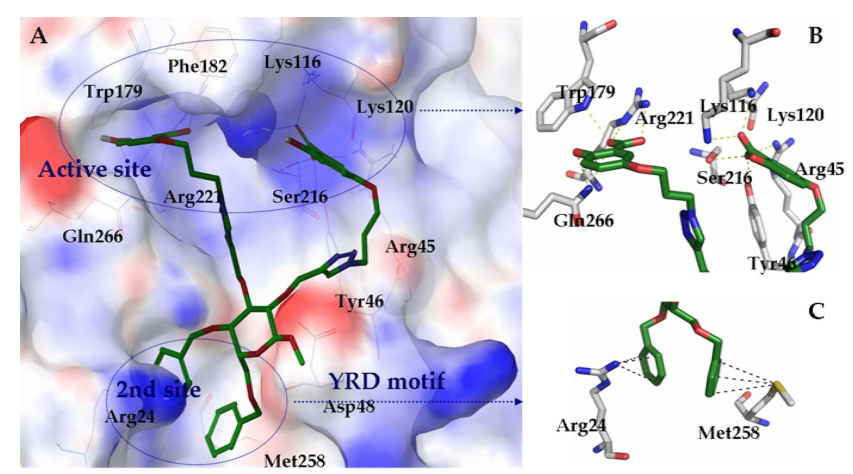

Figure 2. PTP1B in complex with compound 16. The compound is shown as green stick, and residues of the active site in PTP1B shown as light grey line. Nitrogen atoms are in blue and oxygen atoms in red. Hydrogen bonds are shown as yellow dash line and nonpolar interactions shown in black. 
(Schrödinger, LLC, New York, NY, 2005). Then compound 16 was docked into the active site of the protein using the Induced Fit Docking workflow (Schrödinger, LLC, New York, NY, 2005). The center atom was set to be a virtual center of referenced key residues: Phe182, Cys215 and Gly259.

As illustrated in Figure 2A, densely functionalized hydrogen-bonding network was generated between the two salicylic precursors of the molecule and the active site region while additional nonpolar interactions were made between the benzyl groups on the sugar ring with the second site of PTP1B, synergistically fixing compound $\mathbf{1 6}$ in this plausible location. As shown more lucidly in Figure 2B, the carboxylic acid and hydroxyl groups of the glucosyl C3-attached salicylic precursor made six hydrogen bonds with Arg221 and Trp179 in the WPD loop and Gln266. Interestingly, the other salicylic precursor attached on $\mathrm{C} 4$ position of the glucosyl scaffold also generated several hydrogen-bonding interactions with the amino acid residues on peripheric surface of the first site including Ser216, Lys116, Lys120, Arg45, and Tyr46. In addition, as shown in Figure 2C, the distal benzene groups on $\mathrm{C} 4$ and $\mathrm{C} 6$ position of the glucoside made cation-pi interaction with the guanidinium group of Arg24 and hydrophobic interaction with Met258, which may account for the enhancement of the inhibitory activity of this compound compared to our previously prepared glycosides with exposed side-chain hydroxyl groups.

\section{Conclusion}

In summary, we have efficiently prepared in this study a series of bidentate triazolyl glucosides bearing two salicylic precursors on 2,6-, 3,4-, 4,6- and 2,3-position of the central glucosyl scaffold via click chemistry. The following inhibitory assay identified the 2,3-disubstituted glucoside $\mathbf{1 6}$ as the most potent inhibitor with at least 3 -fold enhanced inhibitory activity compared to the rest, which also possesses favorable selectivity over a panel of homologous PTPs. Docking simulation was then conducted to propose a plausible binding mode of this inhibitor with PTP1B and the crucial role of the benzyl groups on the glycosyl moiety for enhancing the binding affinity. Our work presented here would thus provide new insight toward the utilization of monosaccharide as the central scaffold whereas diverse pharmacophores could be flexibly attached for the probing of the structural preference of drug targets.

\section{Experimental Section}

General. Chemicals and solvents are of analytical grade and are used without further purifications. All reactions and chromatographic fractions were monitored by thin-layer chromatography (TLC) using precoated silica gel plates (Yantai Marine Chemical Co. Ltd., China), and spots were visualized either under UV light $(254 \mathrm{~nm})$ or by sulfuric acid spray. Silica gel (200-300 mesh, Yantai Chemical Industry Research Institute, China) was used for column chromato- graphy. ${ }^{1} \mathrm{H}$ and ${ }^{13} \mathrm{C}$ NMR spectra were recorded on a Bruker AM-400 spectrometer using tetramethylsilane (TMS) as the internal standard chemical shifts in ppm. Coupling constants $(J)$ are in hertz. Optical rotations were measured using a Perkin-Elmer 241 polarimeter at room temperature and a 10$\mathrm{cm} 1$-mL cell. High resolution mass spectra (HRMS) were recorded on a Waters LCT Premier XE spectrometer using standard conditions (ESI, $70 \mathrm{eV}$ ).

Synthesis of Methyl 5-(3-bromopropoxy)-2-hydroxybenzoate (4). 3 (1800 mg, $10.7 \mathrm{mmol}$ ) and 1,3-dibromopropane $(1.3 \mathrm{~mL}, 12.9 \mathrm{mmol})$ were dissolved in anhydrous acetonitrile $(30 \mathrm{~mL})$ and heated to $100{ }^{\circ} \mathrm{C}$. Potassium carbonate was added in 3 portions and the resulting mixture was refluxed for 3 hours. The solvent was then removed in vacuo and the residue was taken into ethyl acetate $(60 \mathrm{~mL})$ followed by extraction with $1 \mathrm{~N} \mathrm{HCl}$ and brine and dried with anhydrous $\mathrm{MgSO}_{4}$. Upon concentration in vacuo, the crude product was further purified by column chromatography (Pet/EtOAc, 11:1) to furnish 4 (795 mg, 25.7\%).

Synthesis of Methyl 5-(3-azidopropoxy)-2-hydroxybenzoate (2). To a solution of compound 4 (795 $\mathrm{mg}, 2.75 \mathrm{mmol}$ ) in anhydrous acetonitrile $(30 \mathrm{~mL})$ was added sodium azide $(1.07 \mathrm{~g}, 16.50 \mathrm{mmol})$ and this mixture was stirred at reflux for 3 hours. The solvent was then removed under reduced pressure and the residue was taken into dichloromethane and washed with water and brine. The combined organic layers were dried over anhydrous $\mathrm{MgSO}_{4}$ and concentrated in vacuo to afford a pale yellow product 2 (683 $\mathrm{mg}, 98.9 \%) .{ }^{1} \mathrm{H}$ $\operatorname{NMR}\left(400 \mathrm{MHz}, \mathrm{CDCl}_{3}\right): \delta=10.36(\mathrm{~s}, 1 \mathrm{H}), 7.29(\mathrm{~d}, J=3.1$ $\mathrm{Hz}, 1 \mathrm{H}), 7.07$ (dd, $J=9.0,3.1 \mathrm{~Hz}, 1 \mathrm{H}), 6.91(\mathrm{~d}, J=9.0 \mathrm{~Hz}$, $1 \mathrm{H}), 4.00(\mathrm{t}, J=5.9 \mathrm{~Hz}, 2 \mathrm{H}), 3.94(\mathrm{~s}, 3 \mathrm{H}), 3.51(\mathrm{t}, J=6.6$ $\mathrm{Hz}, 2 \mathrm{H}), 2.08-1.98(\mathrm{~m}, 2 \mathrm{H}) ;{ }^{13} \mathrm{C} \mathrm{NMR}\left(101 \mathrm{MHz}, \mathrm{CDCl}_{3}\right) \delta$ $=170.4,156.4,151.2,124.6,118.7,113.0,112.0,65.4,52.4$, 48.3, 28.9.

General Procedure for the $\boldsymbol{O}$-Propargylation. The alcohol was dissolved in anhydrous DMF and $\mathrm{NaH}$ (3-5 equiv) was added to this mixture at $0{ }^{\circ} \mathrm{C}$, stirring for $20 \mathrm{~min}$. Then propargyl bromide (3-5 equiv) was slowly added at $0{ }^{\circ} \mathrm{C}$ and the mixture was warmed to r.t., stirring for another $12 \mathrm{~h}$. The solvent was then removed and the resulting residue was diluted with EtOAc, washed successively with water and brine. The combined organic layers were dried over $\mathrm{MgSO}_{4}$, filtered and concentrated to give a crude product which was purified by column chromatography, yielding product $\mathbf{5}$ and 7.

Methyl 3,4-di- $O$-benzyl-2,6-di- $O$-propargyl- $\alpha$-D-glucopyranoside (5): Yellow-brown syrup $(90.5 \%) ;[\alpha]_{\mathrm{D}}=+70.0$ (c 0.1, $\mathrm{CH}_{2} \mathrm{Cl}_{2}$ ); ${ }^{1} \mathrm{H}$ NMR (400 MHz, $\left.\mathrm{CDCl}_{3}\right) \delta$ 7.41-7.26 (m, 10H), $4.96(\mathrm{~d}, J=10.8 \mathrm{~Hz}, 1 \mathrm{H}), 4.78(\mathrm{~d}, J=12.4 \mathrm{~Hz}$, $1 \mathrm{H}), 4.66$ (t, $J=12.4 \mathrm{~Hz}, 2 \mathrm{H}), 4.58-4.10(\mathrm{~m}, 5 \mathrm{H}), 3.88(\mathrm{t}, J=$ $9.6 \mathrm{~Hz}, 2 \mathrm{H}), 3.83(\mathrm{dd}, J=3.6,10.4 \mathrm{~Hz}, 1 \mathrm{H}), 3.73-3.70(\mathrm{~m}$, $1 \mathrm{H}), 3.65(\mathrm{dd}, J=2.0,10.4 \mathrm{~Hz}, 1 \mathrm{H}), 3.56(\mathrm{t}, J=9.6 \mathrm{~Hz}, 1 \mathrm{H})$, 3.49 (dd, $J=3.6,9.6 \mathrm{~Hz}, 1 \mathrm{H}), 3.34$ (s, $3 \mathrm{H}), 2.45$ (t, $J=2.4$ $\mathrm{Hz}, 1 \mathrm{H}), 2.38(\mathrm{t}, J=2.4 \mathrm{~Hz}, 1 \mathrm{H}) ;{ }^{13} \mathrm{C}$ NMR $(100 \mathrm{MHz}$, $\left.\mathrm{CDCl}_{3}\right) \delta 138.4,138.1,128.5,128.4,128.3,128.2,128.0$, 127.8, 98.1, 81.7, 80.4, 79.6, 79.5, 76.9, 75.2, 75.1, 74.3, 73.4, 69.7, 68.0, 60.5, 58.6, 55.2; HR(ESI)MS: calcd for 
$\mathrm{C}_{27} \mathrm{H}_{30} \mathrm{O}_{6}+\mathrm{Na} 473.1940$, found 473.2929.

Methyl 2,3-di- $\boldsymbol{O}$-benzyl-4,6-di- $\boldsymbol{O}$-propargyl- $\boldsymbol{\alpha}$-D-glucopyranoside (7): Yellow-brown syrup $(84.0 \%) ;[\alpha]_{\mathrm{D}}=+96.8$ (c 1.2, $\mathrm{CH}_{2} \mathrm{Cl}_{2}$ ); ${ }^{1} \mathrm{H} \mathrm{NMR}\left(400 \mathrm{MHz}, \mathrm{CDCl}_{3}\right) \delta$ 7.40-7.27 $(\mathrm{m}, 10 \mathrm{H}), 4.96(\mathrm{~d}, 1 \mathrm{H}, J=10.8 \mathrm{~Hz}), 4.82(\mathrm{~d}, 1 \mathrm{H}, J=10.8$ $\mathrm{Hz}), 4.78$ (d, 1H, $J=12.0 \mathrm{~Hz}), 4.64(\mathrm{~d}, 1 \mathrm{H}, J=12.0 \mathrm{~Hz})$, 4.59 (d, 1H, $J=3.2 \mathrm{~Hz}), 4.46-4.13(\mathrm{~m}, 2 \mathrm{H}), 4.26-3.96(\mathrm{~m}$, $2 \mathrm{H}), 3.94(\mathrm{t}, 1 \mathrm{H}, J=9.2 \mathrm{~Hz}), 3.83(\mathrm{dd}, 1 \mathrm{H}, J=4.0,10.4 \mathrm{~Hz})$, 3.75-3.71 (m, 2H), 3.51-3.47 (m, 2H), $3.38(\mathrm{~s}, 3 \mathrm{H}), 2.45-$ $2.44(\mathrm{~m}, 2 \mathrm{H}) ;{ }^{13} \mathrm{C} \mathrm{NMR}\left(100 \mathrm{MHz}, \mathrm{CDCl}_{3}\right) \delta 138.6,138.0$, $128.5,128.4,128.2,128.1,128.0,127.0,98.2,81.8,80.1$, 79.6, 79.3, 77.0, 75.8, 75.0, 74.3, 73.4, 69.5, 68.1, 60.1, 58.6, 55.3; HR(ESI)MS: calcd for $\mathrm{C}_{27} \mathrm{H}_{30} \mathrm{O}_{6}+\mathrm{K} 489.1679$, found 489.1682 .

Synthesis of Methyl 2,6-di- $O$-benzyl-3,4-di- $O$-propargyl- $\alpha$-D-glucopyranoside (6). To a solution of $6^{\prime}$ in anhydrous DMF at $0{ }^{\circ} \mathrm{C}, \mathrm{NaH}$ ( 5 equiv.) was added, stirring for 20 min. Propargyl bromide (5 equiv.) was then slowly added at $0{ }^{\circ} \mathrm{C}$, stirring for another $12 \mathrm{~h}$ at r.t. After completion of the reaction, the solvent was removed in vacuum and the resulting residue was diluted with EtOAc, washed successively with water and brine, dried over $\mathrm{MgSO}_{4}$, filtered and concentrated to give crude products. The disilylated glycosyl alkyne was directly dissolved in $\mathrm{MeOH}$, followed by the addition of $\mathrm{AcCl}$ ( 0.5 equiv.), stirring for $6 \mathrm{~h}$. The mixture was then concentrated, extracted with $\mathrm{CH}_{2} \mathrm{Cl}_{2}$, washed with sat. $\mathrm{NaHCO}_{3}$ and brine. The combined organic layers were dried over $\mathrm{MgSO}_{4}$, filtered, and evaporated to give a crude product which was dissolved directly in anhydrous DMF. $\mathrm{NaH}$ (5 equiv.) was added at $0{ }^{\circ} \mathrm{C}$, stirring for $20 \mathrm{~min}$. Then $\mathrm{BnBr}$ (5 equiv.) was added dropwise at $0{ }^{\circ} \mathrm{C}$, stirring for another $12 \mathrm{~h}$ at r.t. Upon completion of the reaction, solvent was removed and the resulting residue was diluted with EtOAc, washed with water and brine. The combined organic layers were dried over $\mathrm{MgSO}_{4}$, filtered and concentrated to give the crude product which was eventually purified by column chromatography. Yellow-brown syrup (56\% for 3 steps); $[\alpha]_{\mathrm{D}}=+76.4\left(c 0.1, \mathrm{CH}_{2} \mathrm{Cl}_{2}\right) ;{ }^{1} \mathrm{H}$ NMR $(400 \mathrm{MHz}$, $\left.\mathrm{CDCl}_{3}\right) \delta 7.40-7.27(\mathrm{~m}, 10 \mathrm{H}), 4.94(\mathrm{~d}, J=3.6 \mathrm{~Hz}, 1 \mathrm{H}), 4.88$ $(\mathrm{d}, J=11.2 \mathrm{~Hz}, 1 \mathrm{H}), 4.79(\mathrm{~d}, J=10.8 \mathrm{~Hz}, 1 \mathrm{H}), 4.65(\mathrm{~d}, J=$ $12.0 \mathrm{~Hz}, 1 \mathrm{H}), 4.57(\mathrm{~d}, J=12.0 \mathrm{~Hz}, 1 \mathrm{H}), 4.41-4.30(\mathrm{~m}, 3 \mathrm{H})$, $4.23(\mathrm{dd}, J=2.0,13.2 \mathrm{~Hz}, 1 \mathrm{H}), 3.92(\mathrm{t}, J=9.2 \mathrm{~Hz}, 1 \mathrm{H})$, 3.76-3.72 (m, 3H), $3.66(\mathrm{dd}, J=3.6 \mathrm{~Hz}, 6.0 \mathrm{~Hz}, 1 \mathrm{H}), 3.56(\mathrm{t}$, $J=9.2 \mathrm{~Hz}, 1 \mathrm{H}), 3.44$ (s, 3H), 2.44 (brs, 1H), 2.40 (brs, 1H); ${ }^{13} \mathrm{C}$ NMR $\left(100 \mathrm{MHz}, \mathrm{CDCl}_{3}\right) \delta 138.5,138.0,128.5,128.4$, $128.2,128.2,128.4,128.0,127.8,127.7,98.1,81.8,80.0$, 79.9, 79.4, 77.4, 75.7, 75.0, 74.4, 73.5, 69.8, 68.7, 60.0, 58.8, 55.2; HR(ESI)MS calcd for $\mathrm{C}_{27} \mathrm{H}_{30} \mathrm{O}_{6}+\mathrm{K} 489.1679$, found 489.1686 .

Synthesis of Methyl 4,6-di- $O$-benzyl-2,3-di- $O$-propargyl- $\alpha$-D-glucopyranoside (8). To a solution of $\mathbf{8}^{\prime}$ (306 mg, $0.82 \mathrm{mmol})$ in $\mathrm{CH}_{2} \mathrm{Cl}_{2}$, TFA $(0.45 \mathrm{~mL}, 5.74 \mathrm{mmol})$ was added. After stirring for $5 \mathrm{~h}$ at r.t., the mixture was neutralized with $\mathrm{NaHCO}_{3}$ and extracted with $\mathrm{CH}_{2} \mathrm{Cl}_{2}$. The combined organic layers were then washed with brine, dried over $\mathrm{MgSO}_{4}$ and concentrated in vacuum to give the crude product which was directly dissolved in anhydrous DMF at
$0{ }^{\circ} \mathrm{C} . \mathrm{NaH}$ (5 equiv) was then added, stirring for $20 \mathrm{~min}$, followed by careful addition of $\operatorname{BnBr}\left(5\right.$ equiv) at $0{ }^{\circ} \mathrm{C}$. The reaction mixture was warmed to r.t. and stirred for another $12 \mathrm{~h}$. Solvent was then removed and the resulting residue was diluted with EtOAc, washed successively with water and brine. The combined organic layers were dried over $\mathrm{MgSO}_{4}$, filtered and concentrated to give the crude product which was purified by column chromatography. Yellowbrown syrup $(70.4 \%$ for 2 steps $) ;[\alpha]_{\mathrm{D}}=+96.8$ (c 1.2, $\left.\mathrm{CH}_{2} \mathrm{Cl}_{2}\right) ;{ }^{1} \mathrm{H} \mathrm{NMR}\left(400 \mathrm{MHz}, \mathrm{CDCl}_{3}\right) \delta 7.36-7.23(\mathrm{~m}, 10 \mathrm{H})$, $4.94(\mathrm{~d}, J=3.2 \mathrm{~Hz}, 1 \mathrm{H}), 4.91(\mathrm{~d}, J=11.2 \mathrm{~Hz}, 1 \mathrm{H}), 4.65$ (d, $J$ $=12.0 \mathrm{~Hz}, 1 \mathrm{H}), 4.54-4.38(\mathrm{~m}, 6 \mathrm{H}), 3.87(\mathrm{t}, J=9.2 \mathrm{~Hz}, 1 \mathrm{H})$, 3.77-3.41 (m, 5H), $3.42(\mathrm{~s}, 3 \mathrm{H}), 2.47(\mathrm{t}, J=2.0 \mathrm{~Hz}, 1 \mathrm{H})$, $2.44(\mathrm{t}, J=2.0 \mathrm{~Hz}, 1 \mathrm{H}) ;{ }^{13} \mathrm{C}$ NMR $\left(100 \mathrm{MHz}, \mathrm{CDCl}_{3}\right) \delta$ $138.1,137.9,128.4,128.3,128.2,128.0,127.8,98.0,81.6$, $80.2,79.8,79.3,77.3,75.2,75.0,74.3,73.5,70.0,68.3,60.4$, 58.7, 55.1; HR(ESI)MS calcd for $\mathrm{C}_{27} \mathrm{H}_{30} \mathrm{O}_{6}+\mathrm{Na} 473.1940$, found 473.1941 .

General Procedure for CuAAC. To a solution of the azide 2 (2.4 equiv.) and di- $O$-propynyl glucoside ( 1 equiv.) in a solvent mixture of water/ $\mathrm{CH}_{2} \mathrm{Cl}_{2}(1: 1, \mathrm{~V} / \mathrm{V}), \mathrm{Na}$ ascorbate ( 4 equiv.) and $\mathrm{CuSO}_{4} \cdot 5 \mathrm{H}_{2} \mathrm{O}$ (2 equiv.) were added at r.t. The resulting mixture was stirred for 8-12 $\mathrm{h}$ and was then diluted with $\mathrm{CH}_{2} \mathrm{Cl}_{2}$, washed with water and saturated EDTA, respectively. The combined organic layers were dried over $\mathrm{MgSO}_{4}$, filtered, concentrated and purified by column chromatography to provide compounds $9, \mathbf{1 0}, 11$ and 12.

3,4-Di-O-benzyl-2,6-di- $O$-\{1-[3-(4-hydroxy-3-(methoxylcarbonyl)phenoxy)propyl]-1H-1,2,3-triazole-4-yl\}- $\alpha$-D-glucopyranoside methyl ether (9): Colorless syrup (80.0\%). $[\alpha]_{\mathrm{D}}-9.2\left(c\right.$ 1.0, $\left.\mathrm{CH}_{2} \mathrm{Cl}_{2}\right) ;{ }^{1} \mathrm{H}$ NMR $\left(400 \mathrm{MHz}, \mathrm{CDCl}_{3}\right) \delta$ $10.38(\mathrm{~s}, 1 \mathrm{H}), 10.36(\mathrm{~s}, 1 \mathrm{H}), 7.47(\mathrm{~s}, 1 \mathrm{H}), 7.36-7.30(\mathrm{~m}, 6 \mathrm{H})$, 7.26-7.21 (m, 5H), 7.05-7.01 (m, 2H), $6.91(\mathrm{~d}, J=6.1 \mathrm{~Hz}$ $1 \mathrm{H}), 6.89(\mathrm{~d}, J=6.1 \mathrm{~Hz}, 1 \mathrm{H}), 5.06(\mathrm{~d}, J=12.1 \mathrm{~Hz}, 1 \mathrm{H}), 4.96$ $(\mathrm{d}, J=12.1 \mathrm{~Hz}, 1 \mathrm{H}), 4.78(\mathrm{~d}, J=11.0 \mathrm{~Hz}, 1 \mathrm{H}), 4.74(\mathrm{~d}, J=$ $8.4 \mathrm{~Hz}, 1 \mathrm{H}) 4.70$ (d, $J=8.8 \mathrm{~Hz}, 1 \mathrm{H}), 4.65-4.59(\mathrm{~m}, 3 \mathrm{H})$, 4.48-4.44 (m, 3H), $4.40(\mathrm{t}, J=6.7 \mathrm{~Hz}, 3 \mathrm{H}), 3.94(\mathrm{~s}, 3 \mathrm{H})$, 3.92 (s, 3H), 3.89-3.81 (m, 4H), 3.77 (dd, $J=3.4 \mathrm{~Hz}, 7.0 \mathrm{~Hz}$, $1 \mathrm{H})$, 3.69-3.67 (m, 2H), 3.55-3.47 (m, 3H), $3.34(\mathrm{~s}, 3 \mathrm{H})$, 2.32-2.21 (m, 4H); ${ }^{13} \mathrm{C}$ NMR (400 MHz, $\left.\mathrm{CDCl}_{3}\right) \delta 170.1$, $156.4,156.3,150.8,150.7,145.5,144.8,138.3,138.1$, $128.5,128.4,128.1,127.9,127.7,127.6,124.4,124.3$, $122.9,122.8,118.7,118.6,112.9,111.9,98.1,81.8,79.7$, 77.3, 74.8, 73.2, 69.9, 68.7, 66.6, 64.9, 64.8, 64.7, 55.2, 52.3, 47.0, 46.8, 29.9, 29.8; HR(ESI)MS calcd. for $\mathrm{C}_{49} \mathrm{H}_{56} \mathrm{~N}_{6} \mathrm{O}_{14}+$ H 953.3933, found 953.3928 .

2,6-Di-O-benzyl-3,4-di-O-\{1-[3-(4-hydroxy-3-(methoxylcarbonyl)phenoxy)propyl]-1 $\boldsymbol{H}$-1,2,3-triazole-4-yl\}- $\alpha$-D-glucopyranoside methyl ether (10): Colorless syrup (83.6\%). $[\alpha]_{\mathrm{D}}-44.4\left(c\right.$ 1.0, $\left.\mathrm{CH}_{2} \mathrm{Cl}_{2}\right) ;{ }^{1} \mathrm{H} \mathrm{NMR}\left(400 \mathrm{MHz}, \mathrm{CDCl}_{3}\right) \delta$ $10.38(\mathrm{~s}, 2 \mathrm{H}), 7.39(\mathrm{~s}, 1 \mathrm{H}), 7.35-7.30(\mathrm{~m}, 7 \mathrm{H}), 7.28(\mathrm{~d}, J=$ $1.8 \mathrm{~Hz}, 1 \mathrm{H}), 7.25-7.23(\mathrm{~m}, 2 \mathrm{H}), 7.15(\mathrm{~s}, 1 \mathrm{H}), 7.06$ (dd, $J=$ $1.0 \mathrm{~Hz}, 3.1 \mathrm{~Hz}, 1 \mathrm{H}), 7.03$ (dd, $J=1.0 \mathrm{~Hz}, 3.1 \mathrm{~Hz}, 1 \mathrm{H}), 6.92$ $(\mathrm{d}, J=0.9 \mathrm{~Hz}, 1 \mathrm{H}), 6.90(\mathrm{~d}, J=0.9 \mathrm{~Hz}, 1 \mathrm{H}), 4.91(\mathrm{~d}, J=11.7$ $\mathrm{Hz}, 1 \mathrm{H}), 4.89-4.78$ (m, 5H), 4.66 (d, J=11.7 Hz, 1H), 4.62 (d, $J=12.1 \mathrm{~Hz}, 1 \mathrm{H}), 4.51(\mathrm{~d}, J=12.1 \mathrm{~Hz}, 1 \mathrm{H}), 4.47-4.40$ (m, 
$4 \mathrm{H}), 3.93(\mathrm{~s}, 3 \mathrm{H}), 3.92(\mathrm{~s}, 3 \mathrm{H}), 3.90-3.86(\mathrm{~m}, 4 \mathrm{H}), 3.75-3.59$ $(\mathrm{m}, 5 \mathrm{H}), 3.38(\mathrm{~s}, 3 \mathrm{H}), 2.32-2.26(\mathrm{~m}, 4 \mathrm{H}) ;{ }^{13} \mathrm{C} \mathrm{NMR}(400$ $\left.\mathrm{MHz}, \mathrm{CDCl}_{3}\right) \delta 170.1,156.4,150.8,145.0,138.1,128.4$, $128.3,127.8,127.7,127.6,127.5,124.4,123.0,122.8$, 118.7, 112.9, 112.8, 111.9, 97.7, 81.8, 79.8, 77.7, 75.4, 73.5, 70.1, 68.5, 66.1, 64.9, 64.8, 64.6, 55.1, 52.4, 47.0, 46.8, 29.9; $\mathrm{HR}(\mathrm{ESI}) \mathrm{MS}$ calcd. for $\mathrm{C}_{49} \mathrm{H}_{56} \mathrm{~N}_{6} \mathrm{O}_{14}+\mathrm{H}$ 953.3933, found 953.3938 .

2,3-Di-O-benzyl-4,6-di- $O$-\{1-[3-(4-hydroxy-3-(methoxylcarbonyl)phenoxy)propyl]-1H-1,2,3-triazole-4-yl\}- $\alpha$-D-glucopyranoside methyl ether (11): Colorless syrup (yield 85.5\%). $[\alpha]_{\mathrm{D}}-5.8\left(\right.$ c $\left.1.0, \mathrm{CH}_{2} \mathrm{Cl}_{2}\right) ;{ }^{1} \mathrm{H} \mathrm{NMR}(400 \mathrm{MHz}$, $\left.\mathrm{CDCl}_{3}\right) \delta 10.37(\mathrm{~s}, 2 \mathrm{H}), 7.65(\mathrm{~s}, 1 \mathrm{H}), 7.38(\mathrm{~s}, 1 \mathrm{H}), 7.37-7.28$ $(\mathrm{m}, 8 \mathrm{H}), 7.25(\mathrm{t}, J=3.1 \mathrm{~Hz}, 2 \mathrm{H}), 7.07-7.03(\mathrm{~m}, 2 \mathrm{H}), 6.91(\mathrm{~d}$, $J=1.9 \mathrm{~Hz}, 1 \mathrm{H}), 6.91(\mathrm{~d}, J=1.9 \mathrm{~Hz}, 1 \mathrm{H}), 4.96(\mathrm{~d}, J=11.0$ $\mathrm{Hz}, 1 \mathrm{H}), 4.90$ (d, $J=11.8 \mathrm{~Hz}, 1 \mathrm{H}), 4.79$ (d, $J=8.9 \mathrm{~Hz}, 1 \mathrm{H})$, $4.74(\mathrm{~d}, J=3.9 \mathrm{~Hz}, 1 \mathrm{H}), 4.71(\mathrm{t}, J=4.5 \mathrm{~Hz}, 1 \mathrm{H}), 4.67-4.57$ $(\mathrm{m}, 4 \mathrm{H}), 4.54(\mathrm{t}, J=6.8 \mathrm{~Hz}, 6.6 \mathrm{~Hz}, 2 \mathrm{H}), 4.47(\mathrm{t}, J=6.8 \mathrm{~Hz}$, $2 \mathrm{H}), 3.93(\mathrm{~s}, 6 \mathrm{H}), 3.91-3.89(\mathrm{~m}, 4 \mathrm{H}), 3.78-3.75(\mathrm{~m}, 1 \mathrm{H})$, $3.70-3.64(\mathrm{~m}, 2 \mathrm{H}), 3.57-3.54(\mathrm{~m}, 1 \mathrm{H}), 3.50(\mathrm{dd}, J=3.6,6.1$ $\mathrm{Hz}, 1 \mathrm{H}), 3.35(\mathrm{~s}, 3 \mathrm{H}), 2.37-2.28(\mathrm{~m}, 4 \mathrm{H}) ;{ }^{13} \mathrm{C} \mathrm{NMR}(400$ $\left.\mathrm{MHz}, \mathrm{CDCl}_{3}\right) \delta 170.1,156.3,150.8,145.1,144.7,138.9$, $138.1,128.5,128.4,128.1,127.9,127.6,124.4,123.2,123.0$, $118.7,112.9,112.8,111.9,98.2,81.8,79.8,77.5,75.6,73.3$, 69.8, 68.6, 66.1, 64.9, 64.8, 55.2, 53.5, 52.4, 47.1, 46.9, 29.9; $\mathrm{HR}$ (ESI)MS calcd. for $\mathrm{C}_{49} \mathrm{H}_{56} \mathrm{~N}_{6} \mathrm{O}_{14}+\mathrm{H}$ 953.3933, found 953.3932 .

4,6-Di- $O$-benzyl-2,3-di- $O$-\{1-[3-(4-hydroxy-3-(methoxylcarbonyl)phenoxy)propyl]-1H-1,2,3-triazole-4-yl\}- $\alpha$-D-glucopyranoside methyl ether (12): Colorless syrup (86.4\%). $[\alpha]_{\mathrm{D}}-52.2\left(c\right.$ 1.0, $\left.\mathrm{CH}_{2} \mathrm{Cl}_{2}\right) ;{ }^{1} \mathrm{H}$ NMR $\left(400 \mathrm{MHz}, \mathrm{CDCl}_{3}\right) \delta$ $10.37(\mathrm{~s}, 1 \mathrm{H}), 10.36(\mathrm{~s}, 1 \mathrm{H}), 7.33-7.24(\mathrm{~m}, 10 \mathrm{H}), 7.18(\mathrm{~d}, J=$ $6.9 \mathrm{~Hz}, 2 \mathrm{H}), 7.05(\mathrm{t}, J=8.6 \mathrm{~Hz}, 8.8 \mathrm{~Hz}, 2 \mathrm{H}), 6.90(\mathrm{~d}, J=2.5$ $\mathrm{Hz}, 2 \mathrm{H}), 6.87(\mathrm{~d}, J=2.6 \mathrm{~Hz}, 2 \mathrm{H}), 5.01-4.76(\mathrm{~m}, 6 \mathrm{H}), 4.63$ $(\mathrm{d}, J=12.1 \mathrm{~Hz}, 2 \mathrm{H}), 4.51-4.46(\mathrm{~m}, 4 \mathrm{H}), 4.12(\mathrm{~d}, J=7.2 \mathrm{~Hz}$, $1 \mathrm{H}), 3.93(\mathrm{~s}, 3 \mathrm{H}), 3.92(\mathrm{~s}, 3 \mathrm{H}), 3.89-3.85(\mathrm{~m}, 3 \mathrm{H}), 3.76-3.41$ $(\mathrm{m}, 7 \mathrm{H}), 3.39(\mathrm{~s}, 3 \mathrm{H}), 2.38-2.25(\mathrm{~m}, 4 \mathrm{H}) ;{ }^{13} \mathrm{C}$ NMR $(400$ $\left.\mathrm{MHz}, \mathrm{CDCl}_{3}\right) \delta 170.2,170.1,156.3,150.9,150.8,138.3$, $137.9,128.4,127.9,127.7,127.6,124.5,124.4,118.6,112.9$, $112.8,111.9,97.7,81.7,79.8,77.6,74.9,73.5,70.1,68.4$, 65.0, 64.8, 55.1, 52.4, 47.1, 47.0, 29.7; HR(ESI)MS calcd. for $\mathrm{C}_{49} \mathrm{H}_{56} \mathrm{~N}_{6} \mathrm{O}_{14}+\mathrm{H}$ 953.3933, found 953.3930.

General Procedure for Saponification. To a solution of methyl ester in THF/water $(4: 1, \mathrm{v} / \mathrm{v})$ was added $\mathrm{LiOH} \cdot \mathrm{H}_{2} \mathrm{O}$ (4.0 equiv./ester), stirring at r.t. overnight. Then the mixture was acidified to $\mathrm{pH}<4$ with $1 \mathrm{~N} \mathrm{HCl}$. The solvent was removed in vacuum and the crude product was purified by column chromatography to furnish compounds $13,14,15$, 16.

3,4-Di-O-benzyl-2,6-di-O-\{1-[3-(4-hydroxy-3-carboxylphenoxy)propyl]-1H-1,2,3-triazole-4-yl\}- $\alpha$-D-glucopyranoside methyl ether (13): Colorless syrup (96.6\%). $[\alpha]_{\mathrm{D}}+2.2$ (c 1.0, $\left.\mathrm{CH}_{3} \mathrm{OH}\right) ;{ }^{1} \mathrm{H} \mathrm{NMR}\left(400 \mathrm{MHz}, \mathrm{CDCl}_{3}\right) \delta 8.10(\mathrm{~s}, 1 \mathrm{H})$, $7.97(\mathrm{~s}, 1 \mathrm{H}), 7.37-7.25(\mathrm{~m}, 10 \mathrm{H}), 7.20(\mathrm{~d}, J=6.8 \mathrm{~Hz}, 2 \mathrm{H})$, $6.99(\mathrm{dd}, J=2.8,6.0 \mathrm{~Hz}, 2 \mathrm{H}), 6.76(\mathrm{dd}, J=2.7,6.2 \mathrm{~Hz}, 2 \mathrm{H})$, $4.88(\mathrm{~d}, J=11.8 \mathrm{~Hz}, 1 \mathrm{H}), 4.79-4.77(\mathrm{~m}, 2 \mathrm{H}), 4.71(\mathrm{~d}, J=$ $10.9 \mathrm{~Hz}, 1 \mathrm{H}), 4.64(\mathrm{~s}, 2 \mathrm{H}), 4.56(\mathrm{~d}, J=12.3 \mathrm{~Hz}, 1 \mathrm{H}), 4.50-$ $4.39(\mathrm{~m}, 7 \mathrm{H}), 3.74(\mathrm{t}, J=9.2 \mathrm{~Hz}, 3 \mathrm{H}), 3.60(\mathrm{~s} b r, 3 \mathrm{H}), 3.55-$ $3.51(\mathrm{~m}, 2 \mathrm{H}), 3.35(\mathrm{~d}, J=9.5 \mathrm{~Hz}, 1 \mathrm{H}), 3.27$ (s, 3H), 2.19$2.15(\mathrm{~m}, 4 \mathrm{H}) ;{ }^{13} \mathrm{C}$ NMR $\left(400 \mathrm{MHz}, \mathrm{CDCl}_{3}\right) \delta 171.7,155.8$, $150.0,144.4,143.7,138.5,138.4,128.2,128.1,127.7$, 127.6, 127.4, 127.4, 124.0, 123.6, 121.9, 117.3, 114.1, 96.8, 80.8, 79.4, 77.1, 73.9, 71.5, 69.6, 68.4, 65.6, 65.1, 65.0, 63.7, 54.5, 46.4, 46.3, 29.5; HR(ESI)MS calcd. for $\mathrm{C}_{47} \mathrm{H}_{52} \mathrm{~N}_{6} \mathrm{O}_{14}+$ H 925.3620 , found 925.3618 .

2,6-Di-O-benzyl-3,4-di-O-\{1-[3-(4-hydroxy-3-carboxylphenoxy)propyl]-1H-1,2,3-triazole-4-yl\}- $\alpha$-D-glucopyranoside methyl ether (14): Colorless syrup (98.5\%). $[\alpha]_{\mathrm{D}}-15.4$ $\left(c 1.0, \mathrm{CH}_{3} \mathrm{OH}\right) ;{ }^{1} \mathrm{H} \mathrm{NMR}\left(400 \mathrm{MHz}, \mathrm{CDCl}_{3}\right) \delta 8.08(\mathrm{~s}, 1 \mathrm{H})$, $7.96(\mathrm{~s}, 1 \mathrm{H}), 7.38-7.24(\mathrm{~m}, 12 \mathrm{H}), 6.97(\mathrm{~d}, J=2.9 \mathrm{~Hz}, 1 \mathrm{H})$, $6.95(\mathrm{~d}, J=2.9 \mathrm{~Hz}, 1 \mathrm{H}), 6.74(\mathrm{~d}, J=8.8 \mathrm{~Hz}, 2 \mathrm{H}), 4.81-4.76$ $(\mathrm{m}, 3 \mathrm{H}), 4.70(\mathrm{~s}, 2 \mathrm{H}), 4.64(\mathrm{t}, J=11.0 \mathrm{~Hz}, 2 \mathrm{H}), 4.51-4.30$ $(\mathrm{m}, 7 \mathrm{H}), 3.68(\mathrm{t}, J=9.0 \mathrm{~Hz}, 2 \mathrm{H}), 3.56-3.44(\mathrm{~m}, 7 \mathrm{H}), 3.26(\mathrm{~s}$, $3 \mathrm{H}), 2.25-2.18(\mathrm{~m}, 4 \mathrm{H}) ;{ }^{13} \mathrm{C} \mathrm{NMR}\left(400 \mathrm{MHz}, \mathrm{CDCl}_{3}\right) \delta 171.7$, 155.9, 149.9, 144.1, 144.0, 138.7, 138.3, 128.2, 128.0, 127.8, $127.6,127.4,127.3,123.9,123.8,121.5,117.1,114.3,114.2$, $96.9,81.1,79.1,77.1,74.3,72.3,69.6,68.6,65.2,65.0,63.2$, 54.4, 46.5, 46.4, 29.6; HR(ESI)MS calcd. for $\mathrm{C}_{47} \mathrm{H}_{52} \mathrm{~N}_{6} \mathrm{O}_{14}+$ H 925.3620 , found 925.3618 .

2,3-Di-O-benzyl-4,6-di-O-\{1-[3-(4-hydroxy-3-carboxylphenoxy)propyl]-1H-1,2,3-triazole-4-yl\}- $\alpha$-D-glucopyranoside methyl ether (15): Colorless syrup (98.2\%). $[\alpha]_{\mathrm{D}}-18.0$ (c 1.0, $\left.\mathrm{CH}_{3} \mathrm{OH}\right) ;{ }^{1} \mathrm{H} \mathrm{NMR}\left(400 \mathrm{MHz}, \mathrm{CDCl}_{3}\right) \delta 8.13(\mathrm{~d}, J=$ $5.8 \mathrm{~Hz}, 1 \mathrm{H}), 8.04(\mathrm{~s}, 1 \mathrm{H}), 7.34-7.29(\mathrm{~m}, 10 \mathrm{H}), 7.24(\mathrm{~s}, 2 \mathrm{H})$, $7.10(\mathrm{dd}, J=2.3 \mathrm{~Hz}, 8.9 \mathrm{~Hz}, 2 \mathrm{H}), 6.87(\mathrm{~d}, J=8.7 \mathrm{~Hz}, 2 \mathrm{H})$, 4.80-4.72 (m, 4H), 4.64-4.46 (m, 9H), $3.91(\mathrm{~s}, 2 \mathrm{H}), 3.90(\mathrm{~s}$, $2 \mathrm{H}), 3.72-3.63(\mathrm{~m}, 2 \mathrm{H}), 3.57-3.45(\mathrm{~m}, 4 \mathrm{H}), 3.26(\mathrm{~s}, 3 \mathrm{H}), 2.13-$ $1.93(\mathrm{~m}, 4 \mathrm{H}) ;{ }^{13} \mathrm{C} \mathrm{NMR}\left(400 \mathrm{MHz}, \mathrm{CDCl}_{3}\right) \delta 171.5,155.5$, 150.5, 143.9, 143.8, 138.7, 138.6, 138.4, 128.2, 128.1, 127.7, $127.6,127.5,127.3,124.0,123.6,118.0,113.6,96.8,81.5$, 81.0, 79.4, 77.3, 77.1, 74.4, 74.3, 73.5, 71.4, 69.6, 68.6, 68.5, $68.4,65.2,65.1,56.0,54.5,46.5,46.4,29.5$; HR(ESI)MS calcd. for $\mathrm{C}_{47} \mathrm{H}_{52} \mathrm{~N}_{6} \mathrm{O}_{14}+\mathrm{H} 925.3620$, found 925.3619 .

4,6-Di-O-benzyl-2,3-di-O-\{1-[3-(4-hydroxy-3-carboxylphenoxy)propyl]-1 $H$-1,2,3-triazole-4-yl\}- $\alpha$-D-glucopyranoside methyl ether (16): Colerless syrup (97.6\%). $[\alpha]_{\mathrm{D}}-10.6$ (c 5.1, $\left.\mathrm{CH}_{3} \mathrm{OH}\right) ;{ }^{1} \mathrm{H} \mathrm{NMR}\left(400 \mathrm{MHz}, \mathrm{CDCl}_{3}\right) \delta 8.16(\mathrm{~s}, 1 \mathrm{H})$, $8.01(\mathrm{~s}, 1 \mathrm{H}), 7.33-7.26(\mathrm{~m}, 10 \mathrm{H}), 7.16(\mathrm{~d}, J=7.6 \mathrm{~Hz}, 2 \mathrm{H})$, 6.86-6.83 (m, 2H), $6.64(\mathrm{~d}, J=7.9 \mathrm{~Hz}, 2 \mathrm{H}), 4.83(\mathrm{~d}, J=11.7$ $\mathrm{Hz}, 1 \mathrm{H}), 4.77$ (d, $J=3.2 \mathrm{~Hz}, 1 \mathrm{H}), 4.74-4.69$ (m, 4H), 4.51$4.38(\mathrm{~m}, 9 \mathrm{H}), 3.86-3.36(\mathrm{~m}, 8 \mathrm{H}), 3.25(\mathrm{~s}, 3 \mathrm{H}), 2.23-2.12(\mathrm{~m}$, $4 \mathrm{H}) ;{ }^{13} \mathrm{C} \mathrm{NMR}\left(400 \mathrm{MHz}, \mathrm{CDCl}_{3}\right) \delta 171.9,155.7,149.6$, $144.3,144.2,138.3,138.2,128.2,128.1,127.7,127.6,127.4$, $124.0,123.8,120.4,116.6,114.8,96.9,96.4,80.8,79.2$, 79.1, 77.2, 74.0, 72.3, 72.2, 69.6, 68.6, 68.5, 65.5, 65.0, 64.9, 63.2, 54.4, 46.5, 29.6, 29.0; HR(ESI)MS calcd. for $\mathrm{C}_{47} \mathrm{H}_{52} \mathrm{~N}_{6} \mathrm{O}_{14}+\mathrm{H}$ 925.3620, found 925.3620 .

Inhibitory Assay. Recombinant human PTP1B catalytic domain was expressed and purified according to procedures described previously. ${ }^{17 a}$ Enzymatic activity of PTP1B was determined at $30^{\circ} \mathrm{C}$ by monitoring the hydrolysis of $p$ NPP. Dephosphorylation of $p$ NPP generates product $p \mathrm{NP}$, which can be monitored at $405 \mathrm{~nm}$. In a typical $100 \mu \mathrm{L}$ assay, mixture containing $50 \mathrm{mM}$ MOPS, $\mathrm{pH}$ 6.5, $2 \mathrm{mM} p \mathrm{NPP}$ and 
recombinant enzymes, PTP1B activities were continuously monitored on a SpectraMax 340 microplate reader at $405 \mathrm{~nm}$ for $2 \mathrm{~min}$ at $30^{\circ} \mathrm{C}$ and the initial rate of the hydrolysis was determined using the early linear region of the enzymatic reaction kinetic curve. For calculating $\mathrm{IC}_{50}$, inhibition assays were performed with $30 \mathrm{nM}$ recombinant enzyme, $2 \mathrm{mM}$ $p$ NPP in $50 \mathrm{mM}$ MOPS at $\mathrm{pH} 6.5$, and the inhibitors diluted around the estimated $\mathrm{IC}_{50}$ values. $\mathrm{IC}_{50}$ was calculated from the nonlinear curve fitting of percent inhibition (inhibition (\%)) vs. inhibitor concentration [I] by using the following equation: inhibition $(\%)=100 /\left\{1+\left(\mathrm{IC}_{50} /[\mathrm{I}]\right) k\right\}$, where $k$ is the Hill coefficient. To study the inhibition selectivity on other PTP family members, human CDC25B, TCPTP, SHP-1, SHP-2 and LARD1 were prepared and assays were performed according to procedures described previously. ${ }^{17 \mathrm{~b}}$

Acknowledgments. Project supported by National Natural Science Foundation of China (Grant No. 20876045, No. 30801405), National Basic Research Program of China (No. 2007CB914201), National Science \& Technology Major Project of China "Key New Drug Creation and Manufacturing Program" (No. 2009ZX09302-001), Shanghai Science and Technology Community (No. 10410702700, 09DZ2291200), Chinese Academy of Sciences (No. KSCX2-YW-R-168) and the Fundamental Research Funds for the Central Universities (No. WK1013002). X.-P. He also gratefully acknowledges the French Embassy in Beijing, China for a cotutored doctorate fellowship.

\section{References}

1. (a) Ernst, B.; Magnani, J. L. Nat. Rev. Drug Discov. 2009, 8, 661. (b) Meutermans, W.; Le, G. T.; Becker, B. ChemMedChem 2006, 1,1164 .

2. Abdel-Magid, A. F.; Maryanoff, C. A.; Mehrman, S. J. Curr. Opin. Drug Discovery Dev. 2001, 4, 776.

3. Elchelby, M.; Payette, P.; Michaliszyn, E.; Cromlish, W.; Collins, S.; Loy, A. L.; Normandin, D.; Cheng, A.; Himms-Hagen, J.; Chan, C. C.; Ramachandran, C.; Gresser, M. J.; Tremblay, M. L.; Kennedy, B. P. Science 1999, 283, 1544.
4. Klaman, L. D.; Boss, O.; Peroni, O. D.; Kim, J. K.; Martino, J. L.; Zabolotny, J. M.; Moghal, N.; Lubkin, M.; Kim, Y. B.; Sharpe, A. H.; Stricker-Krongrad, A.; Shulman, G. I.; Neel, B. G.; Kahn, B. B. Mol. Cell. Biol. 2000, 20, 5479.

5. (a) Zhang, S.; Zhang, Z.-Y. Drug Discov. Today 2007, 12, 373. (b) V. V Vintonyak, A. P Antonchick, D. Rauh, H. Waldmann, Curr. Opin. Chem. Biol. 2009, 13, 272.

6. Liu, S.; Zeng, L.-F.; Wu, L.; Yu, X.; Xue, T.; Gunawan, A. M.; Long, Y.-Q.; Zhang, Z.-Y. J. Am. Chem. Soc. 2008, 130, 17075.

7. Yang, J.-W.; Li, C.; He, X.-P.; Zhao, H.; Gao, L.-X.; Zhang, W.; Shi, X.-X.; Tang, Y.; Li, J.; Chen, G.-R. Bull. Korean Chem. Soc. 2010, 31, 3359.

8. Rostovtsev, V. V.; Green, L. G.; Fokin, V. V.; Sharpless, K. B. Angew. Chem. Int. Ed. 2002, 41, 2596; Angew. Chem. Int. Ed. 2002, 114, 2708.

9. (a) Le Droumaguet, C.; Wang, C.; Wang, Q. Chem. Soc. Rev. 2010, 39, 1233. (b) Mamidyala, S. K.; Finn, M. G. Chem. Soc. Rev. 2010, 39, 1252. (c) Jewett, J. C.; Bertozzi, C. R. Chem. Soc. Rev. 2010, 39, 1272.

10. (a) Deng, Q.; Zheng, R.-R.; Ding, N.-N.; He, X.-P.; Chen, G.-R. Bull. Korean Chem. Soc. 2010, 31, 1055. (b) Lin, L.; Shen, Q.; Chen, G. R.; Xie, J. Bioorg. Med. Chem. 2008, 16, 9757. (c) Lee, J. W.; Lee, U. Y.; Han, S. C.; Kim J. H. Bull. Korean Chem. Soc. 2009, 30, 1001. (d) Song, Y.-J.; Yoo, C.; Hong, J.-T.; Kim, S.-J.; Son, S. U.; Jang, H.-Y. Bull. Korean Chem. Soc. 2008, 29, 1561. (e) Sirion, U.; Lee, J. H.; Bae, Y. J.; Kim, H. J.; Lee, B. S.; Chi, D. Y. Bull. Korean Chem. Soc. 2010, 31, 1843. (f) Zhang, Y.-J.; He, X.-P.; Hu M.; Li, Z.; Shi, X.-X.; Chen, G.-R. Dyes and Pigments 2011, 88, 391.

11. Puius, Y. A.; Zhao, Y.; Sullivan, M.; Lawrence, D. S.; Almo, S. C.; Zhang, Z.-Y. Proc. Natl. Acad. Sci. U. S. A. 1997, 94, 13420.

12. Shrestha, S.; Bharat, R. B.; Lee, K.-H.; Cho, H. Bioorg. Med. Chem. 2007, 15, 6535-6548.

13. Shrestha, S.; Lee, K.-H.; Cho, H. Bull. Korean Chem. Soc. 2004, $25,1303$.

14. Tanaka, N.; Ohnishi, F.; Uchihata, D.; Torii, S.; Nokami, J. Tetrahedron Lett. 2007, 48, 7383.

15. Ortega-Munoz, M.; Perez-Balderas, F.; Morales-Sanfrutos, J.; Hernandez-Mateo, F.; Isac-Garcia, J.; Santoyo-Gonzalez, F. Eur. J. Org. Chem. 2009, 2454.

16. Halmos, T.; Montserret, R.; Filippi, J.; Antonakis, K. Carbohydr. Res. 1987, 170, 57.

17. (a) Zhang, W.; Hong, D.; Zhou, Y.-Y.; Zhang, Y.-N.; Shen, Q.; Li, J.-Y.; Hu, L.-H.; Li, J. Biochim. Biophys. Acta 2006, 1760, 1505. (b) Shi, L.; Yu, H. P.; Zhou, Y. Y.; Du, J. Q.; Shen, Q.; Li, J. Y.; Li, J. Acta Pharmacol. Sin. 2008, 29, 278. 